\title{
Analysis of marine and coastal resources sustainability in Benoa coastal bay reclamation site, Bali
}

\author{
Asri Setianingrum Kenyo Handadari ${ }^{1,2,{ }^{*}}$ and Widodo Setiyo Pranowo ${ }^{2,3}$ \\ ${ }^{1}$ School of Environmental Science, University of Indonesia, Jakarta, Indonesia \\ ${ }^{2}$ Indonesian Ministry of Marine Affairs and Fisheries, Jakarta, Indonesia \\ ${ }^{3}$ Indonesian Naval Postgraduate School (STTAL), Jakarta, Indonesia
}

\begin{abstract}
There are more than 40 reclamation cases in Indonesia during these 10 years. The classical purpose of reclamation addressed for increasing the benefit of natural resources and community welfare, but in fact in some cases it contributes the environmental problem and social conflict. Benoa coastal bay is one of the proposed to be reclaimed by private sector and had declined by most local people. The aims of this research are analyzing the sustainability of marine and coastal resources in Benoa coastal bay reclamation site based on environmental dimension. This research is conducted using quantitative multi-dimensional scaling (MDS) approach for assessing the sustainability of marine and coastal resources. The assessment result shows that the reclamation will made the environmental less sustainability $(49,88 \%$ out of $100 \%)$. Further consideration is needed if the reclamation is still planning to be implemented in Benoa coastal bay.
\end{abstract}

\section{Introduction}

The development of coastal areas through reclamation should pay attention to the concept of sustainable development that takes into account the balance of environmental, social and economic components. This is in line with the Sustainable Development Goals (SDGs) on goal 14 (Life below Water), which is to preserve and maintain sustainability in utilizing the sea, coastal areas and marine resources. That is important, because the expansion of land by reclamation on the coastal areas will permanently change the characteristics of the coastal and marine environment and have a detrimental effect on marine ecosystems [1]. In fact, reclamation activities provide problems both the environmental aspect, as well as socioeconomic. Reclamation land sometimes still has socio-economic value and ecological value in the surrounding ecosystems including the community [2].

The issue of reclamation in Indonesia does not only show environmental problems, but there are conflicts of interest that lead to social conflicts [2]. Several policies dealing with reclamation activities have been provided, but the sharing of authority in the management

\footnotetext{
* Corresponding author: asri.kenyo@gmail.com
} 
of sea, coastal and small islands between central and local government has come to the policy gaps in managing reclamation activities. There also have been several studies dealing with sustainable coastal development models, but there is a vacuum of research on the principle of sustainable development in reclamation activities. The policy of coastal area reclamation should have been well reviewed, then the reclamation activities are true as an effort to increase the benefits of land resources effectively. Therefore, the emergence of environmental problems and social conflict can be minimized [3]. That is needed any tool that can assessing objectively about feasibility of development in sea, coastal, and small islands and how to managing it well.

Benoa Bay is one of the site that planned to be reclaimed by private sector. Benoa bay is still used as livelihoods area and one of sacred religion place for the locals. This research aimed to analyze the sustainability of marine and coastal resources in Benoa coastal bay reclamation site based on environmental dimension. Environmental conditions in Benoa Bay and estimated impacts from reclamation activities in Benoa Bay waters are explained based on physical, chemical, and ecosystem conditions in Benoa Bay.

\section{Methods}

Benoa Bay is a bay in the south Bali region and its coverage area is between two regencies, namely Badung and Denpasar Regency as part of Bali Province. The location is a waters area that is planned to be developed as a tourism center by doing reclamation initiated by private sector. The research area is the coastal bay area directly facing the reclamation plan. Research area can be seen in Figure 1 that predictable will get impact.

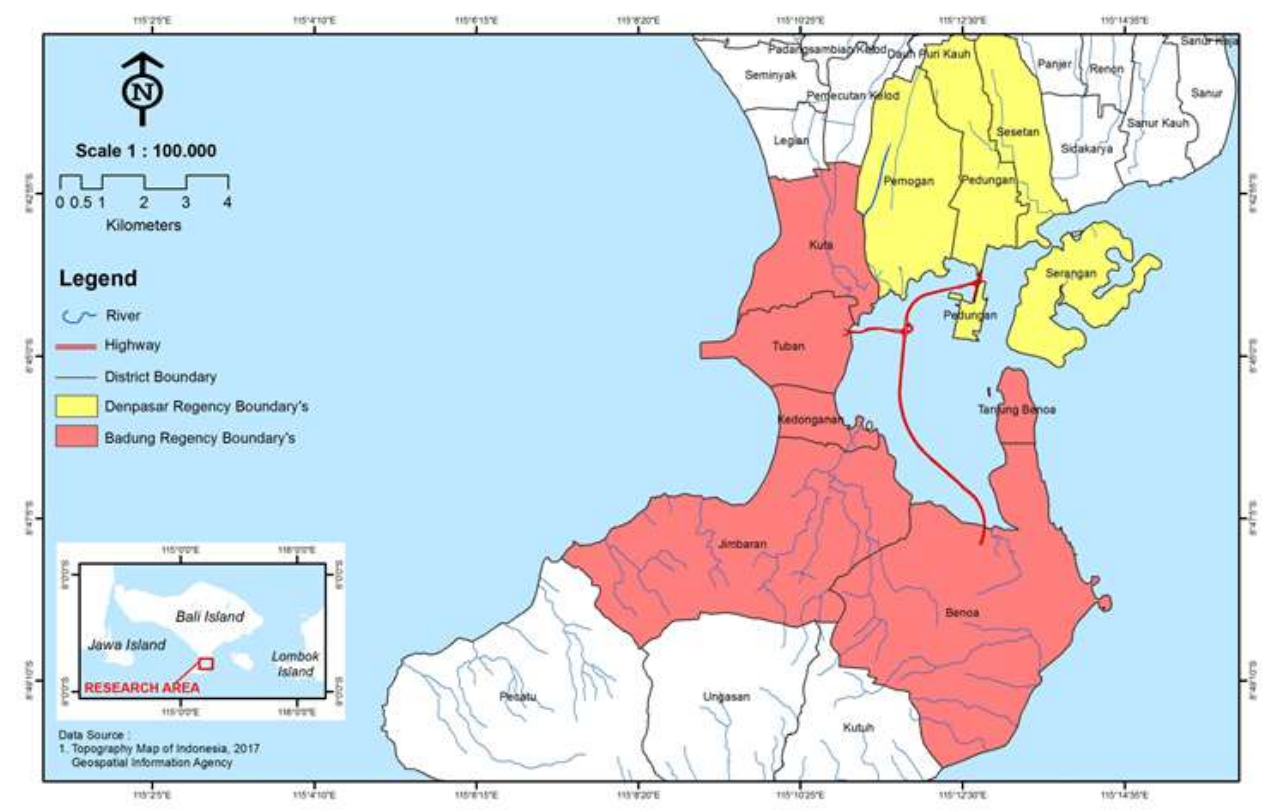

Fig. 1. Map of research area.

The method of research was a combination of qualitative and quantitative methods, consisting of literature review, observation, interviews, questionnaires, and analyzing data with the Multi-Dimensional Analysis method by using the Rapfish software. Rapfish is developed as a new multidisciplinary rapid assessment technique to evaluate the sustainability of fisheries [4]. This software was modified to be able to assess the 
sustainability of marine and coastal resources at the reclamation site in environmental dimension. The attributes chosen for assessing the environmental sustainability in Benoa coastal bay by MDS are Protected Species, Fish Resources, Coral Reefs Ecosystem, Seagrass Ecosystem, Mangrove Ecosystem, Sedimentation, and Flood.

\section{Result and discussion}

Based on the results of the respondents' discussion and literature review, the waters of Benoa Bay have indeed suffered damage and pollution since Serangan Island reclamation (1996), toll road construction, high load of pollutants entering the bay from inland waters due to tourism activities, port activities, and increased sedimentation [5-8]. The environmental conditions in Benoa Bay and the estimated impacts from the reclamation activities in the Benoa Bay are presented based on the physical, chemical and ecosystem aspects in Benoa Bay.

\subsection{Physical marine environment}

Benoa Bay is a bay that has a semi-closed typology with sandy beach and mixed coral fragments. Beach types of the waters of Benoa Bay are sandy beaches. The patterns of sandy beaches are having high potential for erosion or changes in coastlines [9]. There was a depth change in Benoa Bay waters when the conditions in 1995 is compared to the the conditions in 2015. Benoa bay has 7 river estuaries that potentially transporting sediments into the waters [6]. Based on field observations and also seen the condition of Benoa Bay waters had sedimentation at some points. This can be seen in Figure 2 and 3 as the documentation of the researcher at ground check and Benoa Bay waters are estimated occurred sedimentation.

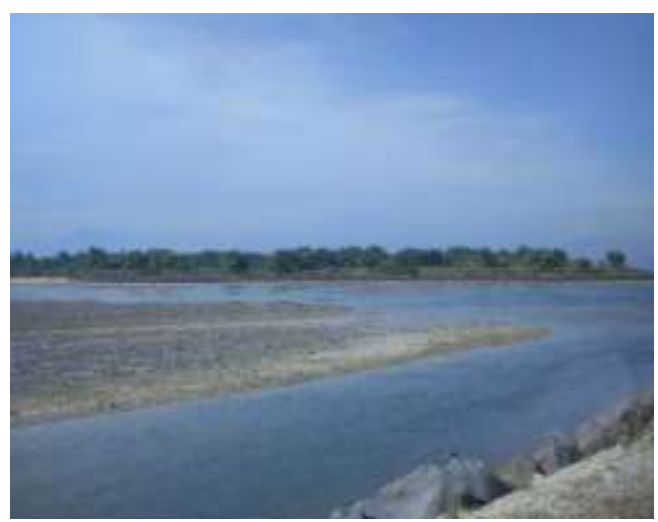

Fig. 2. Benoa Bay Coastal Waters during Ebb Tide (May $2^{\text {nd }}, 2018$ 12.45 WITA).

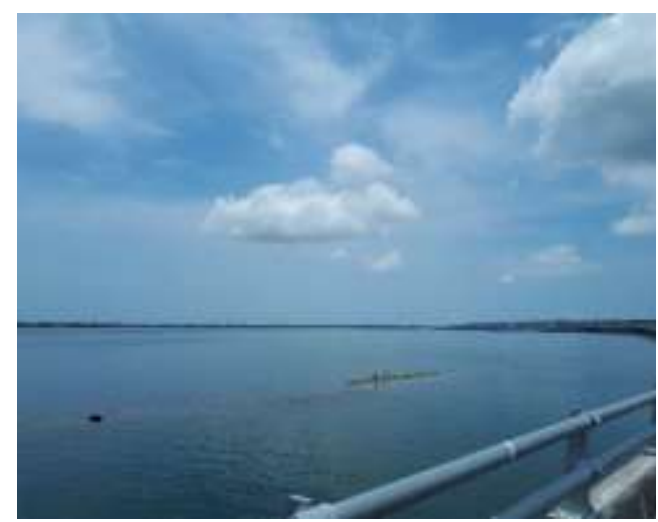

Fig. 3. Benoa Bay Coastal Waters during Ebb to Flood Tide (May, $4^{\text {th }} 2018$ 10.16 WITA).

\subsection{Seawater quality condition}

The results of measurements of sea water quality report in Benoa Bay is categorized as bad or heavily polluted based on sea water quality standards for marine tourism [5]. It is known that there is a value of sea water quality exceed the quality standard for some parameters such as brightness, DO, BOD, nitrate, ammonia, phenol, and coliform. Benoa Bay waters is not indicated as Lead contaminated metal $(\mathrm{Pb})$, but it is indicated to be contaminated by 
Cadmium (Cd), Detergent, and Phenol. Oil and fat contribute significantly to the quality of sea water in the Benoa Bay.

\subsection{Coastal ecosystem condition}

Based on thematic maps the distribution of coastal habitats in 2017 from BIG (Figure 4), is still found in a small distribution of seagrass around the waters of Tanjung Benoa, while for coral reef only found around the outer bay waters. Changes in ecosystem conditions are also in line with the results of research done [6] which states that changes in mangrove cover area from 2006 to 2015 were caused by land conversion for ponds and built zones with a change of $69.07 \mathrm{ha}$, and a decrease in coral cover from 1997 to 2012 covering 90.51 ha. This should be a concern if reclamation is carried out in Benoa Bay waters which has the potential to have turbidity impacts on the bay waters and affect coral cover outside the bay.

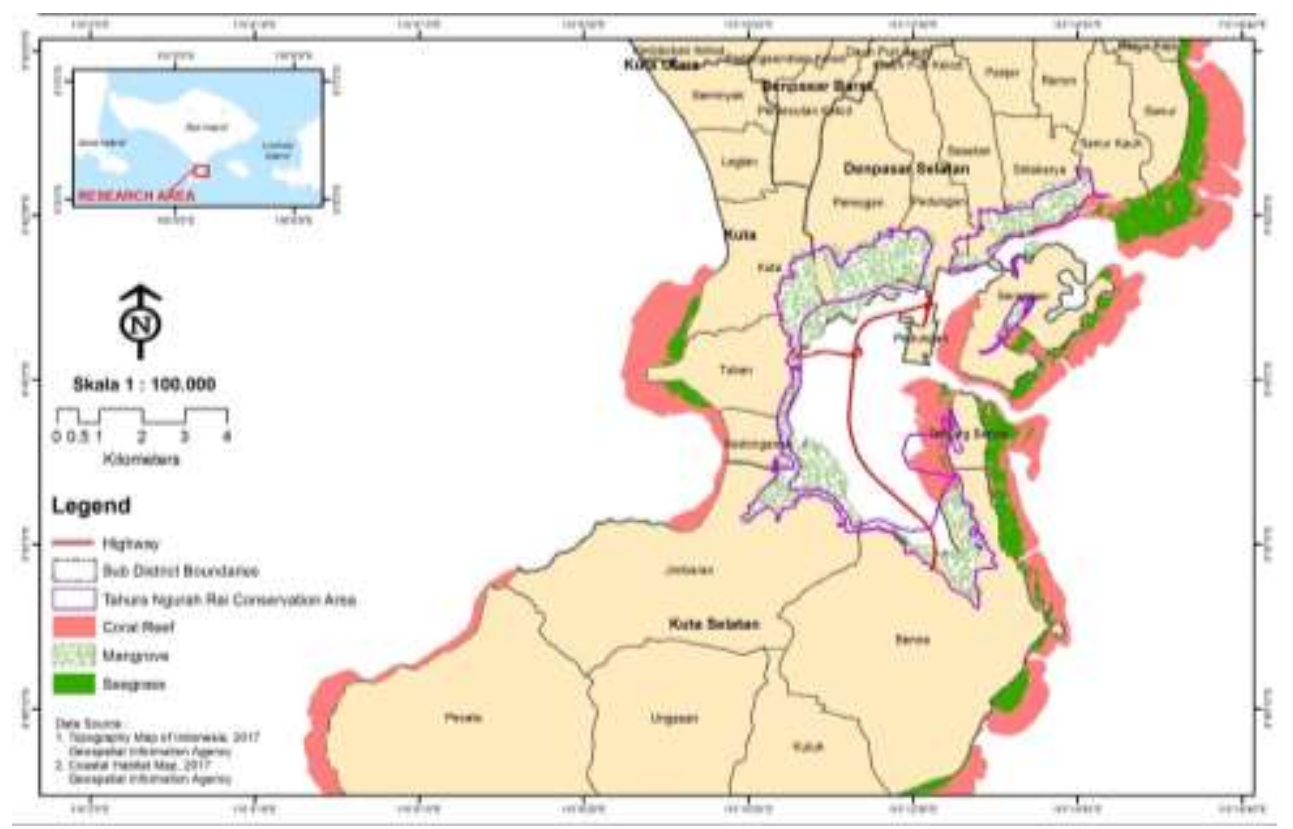

Fig. 4. Map of coastal ecosystem.

\subsection{MDS analysis for marine and coastal environmental}

The result of Rapfish analysis showed the sustainability index value of the environmental dimension is $49.88 \%$ and it is included in the category of Less-sustainable (Figure 5). The leverage of 7 attribute in environmental dimension is the sedimentation potential (Figure 6). This can be interpreted that the sedimentation conditions in Benoa Bay had an important and sensitive role in environmental sustainability in Benoa Bay. Engineering for handling sedimentation must be done as an intervention for the sustainability of the environmental dimension if reclamation is carried out in Benoa Bay. 


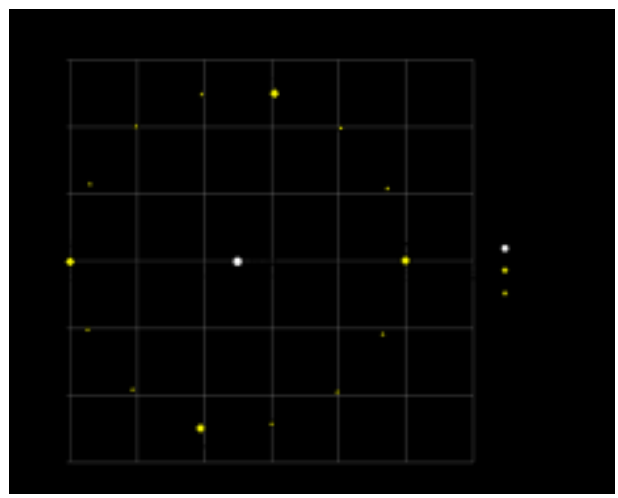

Fig. 5. Environmental sustainability status.

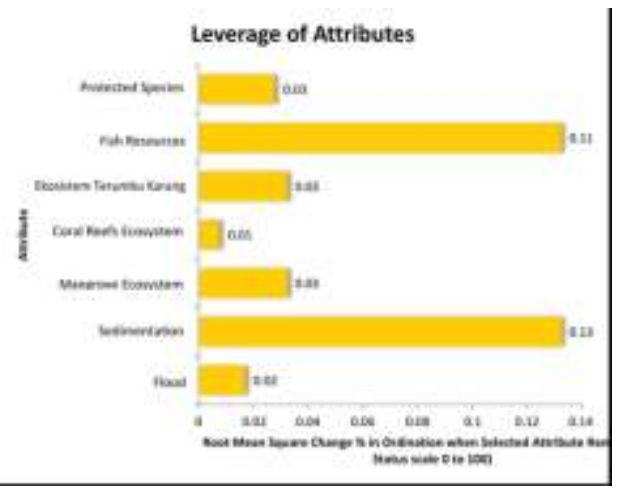

Fig. 6. Leverage of environmental attributes.

\section{Conclusion}

The lack of sustainability of the Benoa bay coastal reclamation plan is triggered from the less values of the environmental dimension. The existing condition of Benoa coastal bay is community livelihood area, and it has been polluted and high sedimentation. Reclamation activities are potential to increasing the seawater turbidity and suspended sediment will transporting beyond the bay. The ecosystem outside of Benoa coastal bay can be also impacted. It is recommended that reclamation in Benoa coastal bay should be reconsidered, due to the lack of sustainability of marine and coastal resources including its function at the reclamation site.

\section{References}

1. B. Peng, C. Lin, D. Jin, H. Rao, Y. Jiang, Y. Liu, Ocean \& Coastal Management 76, 38-44 (2013)

2. S. Pearson, W. Windupranata, S.W. Pranowo, A. Putri, Y. Ma, A. Concejo, E. Fernandez, G. Mendez, J. Banks, A.M. Knights, L.B. Firth, B.B. Breen, R. Jarvis, J.D. Aguirre, S. Chen, A.D.H Smith, P. Steinberg, E. Chatzinikolaou, C. Arvanitidis, Maritime Studies 15, 10.

3. S. Husrin, J. Prihantono, Penambangan Pasir Laut (IPB Press, 2014)

4. T.J. Pitcher, D. Preikshot, Fisheries Research 49, 255-270 (2001)

5. KLHK, Laporan Monitoring Kualitas Air Teluk Benoa Bali (to be published)

6. A. Putra, A.T. Tanto, A.R. Farhan, S. Husrin, W.S. Pranowo, Jurnal Geomatika 23, 2, 87-94 (2017)

7. A.T. Tanto, P. Putra, G. Kusumah, A.R. Farhan, W.S. Pranowo, S. Husrin, Ilham, Jurnal Kelautan Nasional 12, 3, 101-107 (2017)

8. U.J. Wisha, T.A. Tanto, W.S. Pranowo, S. Husrin, Regional Studies in Marine Science 18, 177-187 (2018)

9. B. Triatmodjo, Teknik Pantai (Beta Offset, Jogjakarta, 2016) 